Volume 3 No. 1, Juni 2018

P ISSN 2442-594X | E ISSN 2579-5708

http://journal.iainlangsa.ac.id/index.php/tibyan

DOI: $10.32505 /$ tibyan.v3i1.478

\title{
SYARIAT MENYUSUI DALAM ALQURAN \\ (Kajian Surat Al-Baqarah Ayat 233)
}

Shariat Lets In Alquran (Study of Al-Baqarah, Verse 233)

\author{
Hidayatullah Ismail \\ Dosen Pascasarjana UIN SUSKA Riau \\ hidayatullah.ismail@uin-suska.com
}

\begin{abstract}
This article talks about the ordering of breastfeeding in the Quran through reviewing of Albaqarah verse 233 and then correlated to other supporting verses. In general, breastfeeding is a natural activity of woman who has a child. However, the Qur'an sees it as aprivilege for women, rather than a command of Allah. Breastfeeding is also full of benefits for human being. For advanced discussion, the reasons for the order can be scientifically proven havinga lot of beneficial both psychologically and physically for child and mother. Scientific facts show that the composition of breast milk contains the elements needed by the child that not found in others. Thus, it will physically make the child healthy. The breastfeeding process also helps mothers overcome their psychological problems postpartum, and will strengthen the emotional bond to children (bounding attachment).
\end{abstract}

Keywords: shari'a, breastfeeding, tafseer, scientific fact

\begin{abstract}
Abstrak
Tulisan ini berbicara seputar hukum dan hikmah dibalik pensyariatan menyusui dalam Islam. Secara umum menyusui dipandang sebagai kegiatan alamiah wanita yang memiliki anak. Namun Al-Qur'an memandangnya lebih sebagai perintah Allah swt, selain sebagai suatu bentuk kemuliaan bagi wanita, perintah menyusui juga syarat dengan manfaat dan kemaslahatan bagi manusia. Pada perkembangan selanjutnya alasan-alasan pensyariatan tersebut dapat dibuktikan secara saintifik yang diketahui memiliki banyak kebaikan dan manfaat baik bagi anak maupun ibunya, baik fisik maupun psikis. Fakta ilmiah menunjukkan bahwa komposisi ASI mengandung unsur-unsur yang dibutuhkan oleh tubuh anak dan tidak didapati pada jenis makanan lainnya, sehingga secara fisik akan membuat anak sehat. Secara psikologis proses menyusui juga membantu ibu mengatasi permasalahan psikisnya pasca melahirkan, dan akan mempererat ikatan emosional dengan anak (bounding attachment).
\end{abstract}

Kata Kunci: menyusui, syariat, hukum, hikmah 


\section{Pendahuluan}

Anak merupakan anugerah sekaligus amanah yang besar dari Allah swt kepada para orang tua (ibu dan ayah). Karena begitu besarnya arti seorang anak, sampaisampai kehadirannya sangat dinanti-nanti oleh pasangan suamiistri yang telah menikah. Dalam kilas sejarah, para nabi dan rasul pun banyak memanjatkan doa kepada Allah swt untuk dikaruniai anak. Lihat saja bagaimana doa Nabi Ibrahim a.s dalam QS. Al-Shaffât [37]: 100, doa Nabi Zakariya dalam QS. Âli 'Imrân [3]: 38 dan AlFurqân [25]: 74. Dari semua doa yang dipanjatkan oleh para nabi, tidak hanya meminta karunia sekedar anak keturunan saja, tapi anak keturunan yang berkualitas shâlih, thayyibah, qurrata a'ayun dan imâm al-muttaqîn.

Diantara upaya untuk mendapatkan anak yang thayyibah sejak awal kelahirannya adalah dengan memberikan ASI eksklusif. Menyusuisecaraeksklusifselamaenam bulan diketahui memiliki banyak manfaat, baik untuk ibu maupun untuk bayinya. Meskipun manfaat-manfaat dari menyusui ini telah dipublikasikan di seluruh dunia, angka cakupan ASI eksklusif masih jauh dari yang diharapkan. Hanya 39\% bayi dibawah enam bulan mendapatkan ASI eksklusif pada tahun 2012. Sedangkan data nasional menunjukkan bahwa cakupan ASI eksklusif masih rendah. Menurut Riset kesehatandasar (Riskesdas) tahun 2013, cakupan ASI eksklusif hanya sekitar 38\%, sementarapemerintahmenarget kancaku pan ASIeksklusif sebesar $80 \% .^{1}$

Berbagai faktor telah ditemukan berhubungan dengan rendahnya pemberian ASI eksklusif yaitu factor sosial, psikologi, emosi dan lingkungan. ${ }^{2}$ Ditambahkan lagi berkaitan dengan tempat tinggal, etnis ibu, tingkat pendidikan, tingkat penghasilan, pekerjaan ibu, status merokok ibu, paritas, usia kehamilan, jumlah anak dibawah usia dua tahun, dukungan suami dalam menyusui dan praktik berbagi tempat tidur. ${ }^{3}$ Sehingga beralih kepada asupan selain ASI, baik susu formula maupun makanan penggani ASI lainnya.

Disisi lain, Alquran sebagai hudan dan way of life dalam beberapa kesempatan memerintahkan para ibu untuk menyusukan anaknya hingga dua tahun. ${ }^{4}$ Jika Alquran memerintahkan suatu pekerjaan, tentu di dalamnya ada maslahat dan manfaat. ${ }^{5}$ Sebaliknya, jika perintah tersebut diabaikan, akan memunculkan ketidaksempurnaan pada kehidupan manusia. Untuk itu, maka tulisan ini bertujuan untuk mengulas persoalan seputar menyusui anak dalam Alquran, dengan fokus kajian tafsir surat Al-

\footnotetext{
${ }^{1}$ Adila Prabasiwi, Sandra Fikawati, dan Ahmad Syafiq, ASIE ksklusif dan Persepsi Ketidakcukupan ASI, Kesmas:Jurnal Kesehatan Masyarakat Nasional Vol.9, No.3,Februari2015, h. 282

${ }^{2}$ Aswin Fauziah, Hubungan Antara Pengetahuan Dan Sikap Suami Tentang Pemberian Asi Eksklusif, Fakultas Kedokteran Universitas Muhammadiyah Surakarta, 2013, h. 5

${ }^{3}$ Tan, K.L, Factors Associated with Exclusive Breast feeding among Infants under Sixmonthsof Agein Peninsular Malaysia. International Breastfeeding Journal,Vol.6,2011, h. 2

${ }^{4}$ QS. Al-Baqarah [2]: 233, QS. Luqmân [31]: 14, QS. Al-Ahqâf [46]: 15

${ }^{5}$ Tim FKI Ahla Sufah, Tafsir Maqashidi, (Lirboyo: Lirboyo Press, 2013), h. 2-3
} 
Baqarah ayat 233 dimana perintah menyusui pertama kali ditemukan dalam urutan mushaf Alquran.

\section{Pengertian Istilah}

Kata 'menyusui' dalam Kamus Bahasa Indonesia diartikan dengan "memberikan air susu untuk diminum kepada bayi dari buah dada". ${ }^{6}$ Sedangkan dalam bahasa Alquran, setidaknya ada dua term yang digunakan untuk menunjukkan pada kegiatan yang berkait an dengan menyusui, yaitu:

Pertama, digunakan kata kerja radhi'a-yardha'u-radhâ'an-radhâ'atan, untuk menunjukkan makna pada kegiatan menyusui. ${ }^{7}$ Secara bahasa kata al-radhâ'a bermakna menyusui, baik itu seorang perempuan atau pun binatang. Sedangkan secara istilah berarti menyampaikan air susu seorang perempuan kepada mulut bayi yang belum sampai usianya dua tahun. ${ }^{8}$

Kata ini terulang sebanyak 10 kali dengan berbagai derivasinya dalam Alquran dan tersebar dalam 5 surat, yaitu: QS. Al-Baqarah [2]: 233, QS. Al-Nisâ' [4]: 23, QS. Al-Hajj [22]: 2, Al-Qashash [28]: 7 dan 12, QS. Al-Thalâq [65]: $6 .{ }^{9}$

Kedua, digunakan juga istilah fishâl, yang merujuk pada makna menyapih. Secara bahasa fishâl bermakna fithâm, yaitu menceraikan. ${ }^{10}$ Maksud menceraikan disini yakni pemisahan anak dari susuan, atau pemisahan susuan karena anak terpisah dari asupan susu ibunya dan beralih kepada asupan makanan lainnya. Menurut gramatikal bahasanya, fishâl mengandung makna 'saling memisahkan', sebab anak terpisah dari ibunya, dan ibu pun terpisah dari anaknya, sehinga antara keduanya ada pemisahan. ${ }^{11}$ Kata ini terulang sebanyak 3 kali dalam Al Qur'an, yaitu pada QS. Al-Baqarah [2]: 233, QS. Luqmân [31]: 14 dan QS. Al-Ahqâf [46]: 15. ${ }^{12}$

Dari kedua term yang digunakan dalam Alquran menunjukkan proses menyusui dan pemisahan anak dari susuan ibunya. Dan pengertian kedua term di atas sangat berguna untuk memahami lebih lanjut konteks pembahasan dalam studi ini.

\section{Tafsir Surat Al-Baqarah Ayat 233}

Dari beberapa kali pengulangan kata radha'a dan derivasinya yang sebanyak 10 kali dalam Alquran sebagaimana disebutkan di atas, dalam QS. Al-Baqarah [2]: 233 lah perintah menyusui pertama kali ditemukan dalam mushaf Alquran, Allah swt berfirman:

\footnotetext{
${ }^{6}$ Tim Penyusun, Kamus BahasaIndonesia, (Jakarta: Pusat Bahasa DEPDIKNAS, 2008), hlm. 1398

${ }^{7}$ Mahmud Yunus, Kamus Arab-Indonesia, (Jakarta: Hidakarya Agung, 1990), cet. VIII, h. 143. Lihat juga Ibnu Manzhûr, Lisan Al-'Arab, Tt: Tp, h. 1660

8،Abdurrahman al Jazîriy, Kitab Al-Fiqh 'alâ Madzâhibi Al-Arba'ah, jilid. 4, (Beirut: Dar AlKutub Al-‘Alamiyah, 2003), h. 23

${ }^{9}$ Muhammad Fuâd Abd Al-Bâqiy, Mu'jam Al-Mufahras li Alfâzh Al-Qur'ân Al-Karîm, (Kairo: Dar Al-Hadits, 1346 H), h. 321

${ }^{10}$ Ibnu Manzhûr, Lisân Al-Arâb, hlm. 3423

${ }^{11}$ Muhammad 'Ali Al-Shabuniy, Shafwat Al-Tafâsir, jilid. 1, (Beirut: Dar Al-Qur'ân Al-Karîm, 1981/1401 H), h. 150

${ }^{12}$ Muhammad Fuâd Abd Al-Bâqiy, Mu'jam Al-Mufahras li Alfâzh Al-Qur'ân Al-Karîm,), h. 521
} 


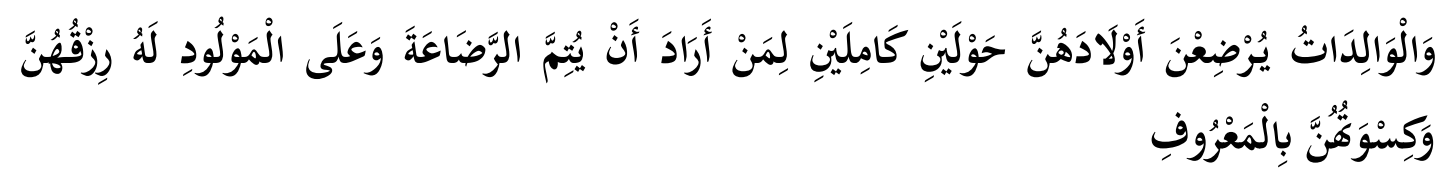

Artinya: "Para ibu hendaklah menyusui anak-anaknya selama dua tahun penuh, yaitu bagi yang ingin menyempurnakan penyusuan. Dan kewajiban ayah memberikan makan dan pakaian kepada para ibu dengan cara yang ma'ruf", (QS. Al-Baqarah [2]: 233)

Pada dasarnya ayat ini merupakan kelanjutan dari episode yang dibicarakan pada ayat sebelumnya, yaitu perihal hukum nikah dan talak yang berakhir pada perpisahan suami-istri. Dan boleh jadi mereka memiliki anak yang masih dalam masa penyusuan. Maka melalui ayat ini Allah swt memerintahkan para istri yang telah ditalak untuk tetap menyusui anak-anaknya. ${ }^{13}$

Lebih lanjut, Wahbah Al-Zuhailiy menerangkan bahwa ayat ini ditujukan bagi wanita-wanita yang ditalak maupun tidak, keduanya diperintahkan untuk menyusui anak-anak mereka selama dua tahun penuh dan tidak lebih dari itu. Namun demikian, tidak ada larangan untuk menyusui anak-anak dalam masa yang kurang dari dua tahun jika memang dipandang akan ada maslahat di dalamnya. ${ }^{14}$ Imam Ibnu Katsir memandang ayat ini sebagai bimbingan Allah swt bagi para ibu, hendaknya mereka menyusui anak-anaknya secara sempurna, yaitu selama dua tahun. ${ }^{15}$

Jika dicermati dalam teks ayat di atas digunakan kata يُزْضِعْنَ yang secara kebahasaan berbentuk fi'il mudhâri', yaitu bentuk kata kerja untuk menunjukkan perbuatan masa sekarang dan akan datang. Untuk itu dapat dipahami bahwa Allah swt melalui ayat ini menginginkan para ibu untuk menyusukan anak-anaknya secara berkelanjutan, sejak awal kelahiran hingga masa sempurna penyusuan, yaitu dua tahun.

Perintah menyusui anak sejak awal kelahiran juga pernah Allah swt perintahkan kepada ibu Nabi Musa as, seperti diceritakan dalam QS. Al-Qashash [28]: 7: "Dan Kami ilhamkan kepada ibu Musa; "susuilah dia, dan apabila kamu khawatir terhadapnya, maka jatuhkanlah dia ke sungai (Nil)...". Dalam ayat ini Allah memerintahkan ibu Musa as untuk segera menyusi anaknya sesaat setelah melahirkan. Menurut Wahbah Al-Zuhailiy, ibu Musa as menyusui selama tiga atau empat bulan. ${ }^{16}$

Hal ini sejalan dengan konsep dasar dalam dunia kesehatan yang menyebutkan bahwa ASI merupakan makanan yang terbaik bagi anak-anak hingga usia dua tahun sebagaimana disepakati oleh para ahli ilmu kedokteran. ASI merupakan makanan dan minuman pokok yang hanya boleh dikonsumsi oleh bayi yang baru lahir dan diberikan secara cepat/ sedini mungkin setelah kelahiran (1 jam setelah lahir). ${ }^{17}$ Dan dianjurkan

\footnotetext{
${ }^{13}$ Muhammad 'Ali Al-Shabuniy, Shafwat Al-Tafâsir, jilid. 1, h. 149-150

${ }^{14}$ Wahbah Al-Zuhailiy, Tafsîr Al-Munîr, jilid 1, (Damaskus: Dar Al-Fikr, 2009), cet. x, h. 730

${ }^{15} \mathrm{Abu}$ Al-Fidâ' Ibnu Katsîr, Tafsir Al-Qur'ân Al- 'Azhîm, terj. M. Abdul Ghafar, jilid 1, (Jakarta: Pustaka Imam Syafi, 2005), h. 468

${ }^{16}$ Wahbah Al-Zuhailiy, Tafsîr Al-Munîr, jilid 10, h. 423

${ }^{17}$ Menyusui sejak awal kelahiran (1 jam setelah kelahiran) dikenal denga Inisiasi Menyusi Dini (IMD). Kementrian Kesehatan RI, Buku Kesehatan Ibu dan Anak, (Jakarta: Kemesnkes, 1997), h. 34
} 
untuk memberikan ASI kepada bayi sesering mungkin sesuai keiinginan bayi (on demand), atau sesuai keiinginan ibu (jika payudara terasa penuh), atau sesuai kebutuhan bayi yaitu setiap dua-tiga jam (paling sedikit empat jam) sekali. ${ }^{18}$

Lebih lanjut, para ahli juga bersepakat bahwa memberikan ASI ekslusif kepada bayi sangat dianjurkan karena memiliki banyak sekali kebaikan, baik untuk bayi maupun untuk ibunya. ASI eksklusif adalah ASI yang diberikan kepada bayi sebagai asupan makanan dan minuman tanpa ditambah dengan jenis makanan atau minuman pendamping apapun. ${ }^{19}$ Pada awalnya pemberian ASI ekslusif dianjurkan sejak awal kelahiran hingga bayi berusia empat bulan, namun pada perkembangannya anjuran tersebut diperpanjang hingga enam bulan. ${ }^{20}$ Sebab komposisi ASI sampai dengan enam bulan tersebut sudah cukup untuk memenuhi gizi bayi meskipun tanpa makanan tambahan atau produk pendamping.

Pada tahapan selanjutnya, ASI diberikan kepada bayi dengan tambahan makanan lunak atau padat yang disebut dengan Makanan Pendamping ASI (MPASI) hingga mencapai usia dua tahun. ${ }^{21}$ Pemberian ASI dianjurkan hingga usia anak mencapai dua tahun sebabdua atau 1000 hari pertama kehidupan merupakan usia emas anak. Masa itulah yang memengaruhi anak menjadi sehat atau cerdas ketika dewasa nanti. Maka, gizi yang baik dan seimbang, termasuk pemberian ASI pada 1000 hari pertama kehidupan harus terpenuhi. ${ }^{22}$

Inilah isyarat manfaat mengapa Allah swt memerintahkan para ibu untuk menyusui anak-anaknya hingga usia dua tahun, sebagaimana firman Allah swt: حوَلَيَنِ كَامِلَيْنِ Dan setelah masa itu, Allah membimbing untuk mulai menyapih anak, sebagaimana digambarkan dalam firman-Nya QS. Luqmân [31]: 14: “...ibunya telah mengandungnya dalam keadaan lemah yang bertambah-tambah, dan menyapihnya dalam dua tahun..." Dan dalam QS. Al-Ahqâf [46]: 15: Mengandungnya dan menyapihnya itu adalah tiga puluh bulan". Sehingga masa dua tahun merupakan masa kesempurnaan susuan seorang ibu kepada anaknya. Isyarat lain yang ditunjukkan adalah bahwa pendidikan anak pada rentang usia nol hingga dua tahun berada di pangkuan ibunya. Untuk itu ibu harus memaksimalkan pendidikan pada masa penting tersebut.

Jika diperhatikan secara seksama firman Allah swt dalam QS. Al-Baqarah [2]: 233, terdapat perpindahan makna yang tergambar dari penggunaan dhamîr mudzakkar pada penggalan لََِِنْ أَرَادَ. Ini mengindikasikan bahwa pada dasarnya keputusan mengenai lama waktu masa penyusuan anak ditentukan oleh suami. Meskipun demikian, dalam

\footnotetext{
${ }^{18}$ Ai Yeyeh Rukiyah dan Lia Yulianti, Asuhan Neonatus Bayi dan Balita, (Jakarta: CV Trans Info Media, 2010), h. 66

${ }^{19}$ Ari Sulistyawati, Buku Ajar Asuhan Kebidanan pada Ibu Nifas, (Yogyakarta: CV. Andi Offset, 2009), h. 24

${ }^{20}$ Pusat Data dan Informasi Kementrian Kesehatan RI, Situasi dan Analisis ASI Eksklusif, (Jakarta: Kemenkes, 2014), h. 1

${ }^{21}$ Ai Yeyeh Rukiyah dan Lia Yulianti, Asuhan Neonatus Bayi dan Balita, h. 67

${ }^{22}$ https://health.kompas.com/read/2016/09/04/193900323/ayo.lanjutkan.pemberian.asi.sampai.usia.d ua.tahun. Diakses pada 11 April 2018
} 
lanjutan ayat ini memerintahkan agar keputusan mengenai masa penyapihan anak

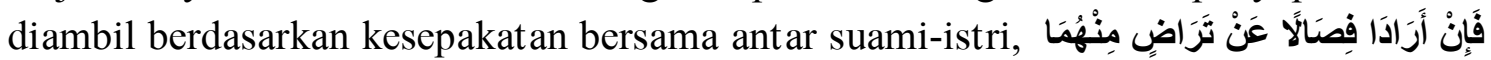

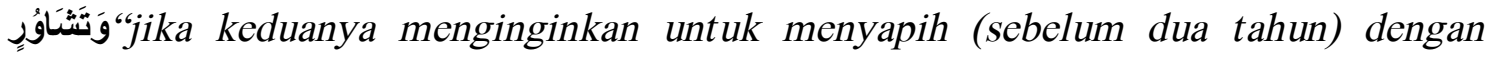
kerelaan keduanya dan pemusyawaratan".

Pada segmen selanjutnya Allah swt ingin menunjukkan betapa agungnya syariat Islam, dimana setelah berbicara mengenai tugas istri untuk menyusui anaknya sebagai bentuk kemuliaan baginya, Allah swt juga berbicara tentang tugas suami. Ada dua kewajiban suami sebagai bentuk dukungan bagi istri yang tengah menyusui, yaitu

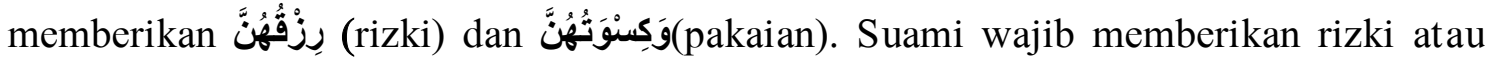
nafkah yang halal, sebab ibu menyusui memerlukan banyak nutrisi dan makanan yang bergizi untuk menghasilkan air susu yang baik. ${ }^{23}$

Suami juga wajib memberikan pakaian yang baik sebab banyak dari wanita memiliki ukuran dan bentuk tubuh yang berbeda dari sebelumnya, sehingga boleh jadi pakaiannya yang lama tidak lagi sesuai di tubuhnya dan memerlukan pakaian yang baru. Selain itu boleh jadi pakaian-pakaian sebelumnya tidak sesuai kondisi ibu menyusui, diperlukan pakaian dengan model dan bentuk yang dapat memudahkan dan nyaman dalam proses menyusui. Tinjauan psikologis, memberikan pakaian yang baru juga akan menimbulkan rasa bahagia pada ibu yang menyusui sebagai bentuk hadiah. Intinya ayat ini menghendaki para suami turut memberikan support dan arahan kepada istri untuk menyusui anaknya, dan sebaiknya hingga sempurna dua tahun. Sebab penelitian menunjukkan bahwa diantara faktor yang menyebabkan seorang istri tidak menyusui anaknya ialah karena tidak ada atau kurangnya dukungan suami. ${ }^{24}$

Mengingat begitu pentingnya pemberian ASI bagi bayi sebab tidak ada susu atau minuman dan makanan apapun yang sepadan dengan kebaikan ASI. Bahkan bagi para ibu yang tidak dapat menyusui anaknya sendiri sebab alasan-alasan tertentu, Allah melalui firmanNya dalam Alquran tidak menganjurkan para orang tua untuk memberikan makanan atau minuman lain sebagai pengganti ASI. Akan tetapi Allah swt membimbing agar orang tua dapat mencarikan perempuan lain untuk menyusukan anak-anak mereka. Meskipun mereka harus mengeluarkan biaya untuk upah. Sebagaimana Allah firmankan dalam lanjutan QS Al-Baqarah [2]: 233:

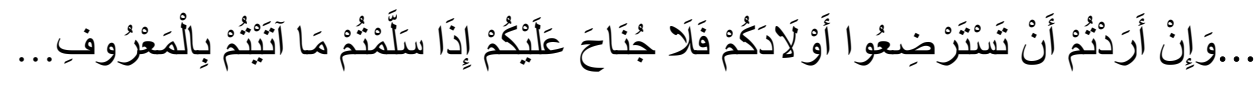

Artinya: “... dan jika kamu ingin anakmu disusukan oleh orang lain, maka tidak berdosa bagimu apabila kamu memberikan pembayaran menurut yang patut...”. (QS Al-Baqarah [2]: 233)

Juga QS. Al-Thalâq [65]: 6:

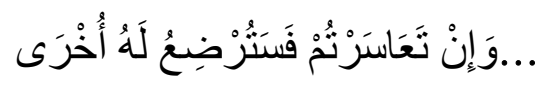

\footnotetext{
${ }^{23}$ Ari Sulistyawati, Buku Ajar Asuhan Kebidanan pada Ibu Nifas, h. 97

${ }^{24}$ Wafi Nur Muslihatun, Asuhan Neonatus Bayi dan Balita, (Tt: Fitramaya, Tt), h. 41
} 
Artinya: “...dan jika kamu menemui kesulitan maka perempuan lain boleh menyusukan (anak itu) untuknya”. (QS. Al-Thalâq [65]: 6)

Imam Ibnu Katsîr menerangkan ayat ini memiliki maksud jika pasangan suami istri yang telah bercerai berbeda pendapat, dimana sang ibu tidak bersedia menyusukan anaknya karena ketidaksesuaian upah yang diberikan oleh sang ayah, maka ia boleh menyusukan anaknya kepada perempuan lain. Namun seandainya sang ibu menyetujui pembayarannya, maka ia lebih berhak menyusukan anaknya. ${ }^{25}$

Meskipun demikian, dalam konteks pasangan suami istri yang tidak bercerai pun ayat ini tetap berlaku, tentu saja dengan konteks 'kesulitan' yang sesuai, seperti masalah kesehatan pada ibu sehingga tidak dapat menyusui anaknya secara langsung, atau kesulitan-kesulitan lainnya. Yang jelas poin yang dapat diambil adalah bahwa kedudukan ASI tidak dapat digantikan dengan jenis makanan atau minuman lainnya bagi bayi. Atau dengan kata lain, lebih baik disusukan oleh perempuan lain dari pada beralih pada susu atau makanan pengganti ASI lainnya.

Hal ini tentu saja nampak berbeda dengan realita yang ada saat ini, dimana para ibu yang tidak dapat menyusui anaknya secara langsung disebabkan alasan-alasan kesehatan, justru memilih beralih pada susu formula atau makanan pengganti ASI lainnya. Bahkan para ibu yang secara medis tidak memiliki masalah apapun tetap saja enggan memberi ASI kepada anaknya, dengan alasan kesibukan atau ingin menjaga penampilan dan berbagai alasan yang tidak syar'i lainnya. Dan ini jelas tidak sesuai dengan syariat yang Allah swt ajarkan dalam firman-Nya di atas. Atau dalam bahasa yang lebih lugas, menentang fitrah yang ada dalam diri seorang ibu, dan merusak pendidikan anaknya.

Padahal pemberian ASI tidak selamanya harus langsung dari payudara ibunya, sebab ASI yang ditampung dari payudara ibu dan ditunda pemberiannya relatif masih memiliki kualitas yang sama, dengan syarat metode penyimpanannya tepat. Intinya, dengan alasan apapun, dan jika tidak menimbulkan kemudharatan, ibu harus terus menyusui anaknya hingga sempurnanya penyusuan, sebab ini merupakan bentuk kemuliaan yang Allah swt berikan.

\section{Syari'at Menyusui}

Sebagian ulama berpendapat, bahwa seorang ibu berkewajiban menyusui anaknya, berdasarkan zhahir ayat QS. Al-Baqarah [2]: 233, karena meskipun secara teks ayat tersebut berbentuk kalimat berita (khabariyah), tetapi mengandung makna perintah. ${ }^{26}$

Menurut Imam Malik, Ibu yang masih berstatus sebagai istri berkewajiban menyusui anaknya, atau dalam keadaan apabila anak tidak dapat menerima susu perempuan lain, atau apabila ayah tidak ada. Tetapi mereka mengecualikan perempuan syarifah (keturunan Rasulullah saw), berdasarkan pada kebiasaan yang berlaku. Adapun

\footnotetext{
${ }^{25}$ Abu Al-Fidâ' Ibnu Katsîr, Tafsir Al Qur'ân al 'Azhîm, terj, jilid 8, h, 220

${ }^{26}$ Muhammad 'Ali Al-Shabuniy, Rawâi' Al-Bayân Tafsîr Âyât min Al-Qur'ân, terj, Ahmad Dzulfikar, jilid, I, (Depok: Keira, 2016), h. 355
} 
perempuan yang ditalak ba'in, ia tidak wajib menyusui. Sebab penyusuan merupakan kewajiban suami, kecuali jika istri atas kehendaknya sendiri mau menyusui, dan dia berhak menerima nafkah yang sepantasnya. ${ }^{27}$

Tetapi mayoritas ulama berpendapat, bahwa perintah menyusui hukumnya adalah sunnah. Kecuali ternyata anak tidak dapat menyusu dari perempuan lain, atau ayah tidak mampu memberikan upah untuk perempuan lain untuk menyusukan anaknya, atau memang jika tidak dijumpai seorang perempuan yang siap menyusui. Alasan mengapa hukumnya menjadi sunnah, tidak lain karena didasarkan pada firman Allah dalam QS. Al-Thalâq [65]: 6: "Jika kamu menemui kesukaran, maka perempuan lain boleh dimintai untuk menyusui (anak itu) untuknya”. Seandainya menyusui hukumnya wajib, niscaya syara' akan memaksa ibu supaya menyusui anaknya. Dengan dasar itulah, maka hukumnya menjadi sunnah, sebab air susu ibunyalah yang paling baik bagi anak dan kasih sayang ibu sendiri jauh lebih banyak..$^{28}$

Selanjutnya mengenai lama waktu menyusui, sebagaimana disinggung di atas bahwa pembatasan masa dua tahun dalam Alquran bukanlah suatu wajib. ${ }^{29}$ Akan tetapi lebih diserahkan kepada kedua orang tuanya untuk menyepakati, apakah kurang dari dua tahun, atau sempurna dua tahun, atau bahkan lebih dari dua tahun. Namun yang menjadi pertimbangan adalah tidak terjadinya suatu mudharat, baik bagi anak maupun ibu.

Mengenai batasan waktu menyusui ini pun menjadi pembahasan oleh para imam mazhab, yaitu terkait susuan yang mengakibatkan seseorang menjadi mahram. Imam Malik, Syafi'i dan Ahmad sepakat bahwa batasan susuan yang menjadikan sebab mahram adalah anak usia dua tahun kebawah, maka lebih dari itu tidak menyebabkan seseorang menjadi mahram. Sedangkan Imam Abu Hanifah berpendapat bahwa batasan susuan mahram adalah 30 bulan. ${ }^{30}$ Imam Al-Qurthubiy lebih cenderung setuju dengan pendapat mayoritas imam madzhab, yaitu bahwa batasan susuan menjadi mahram adalah dua tahun ke bawah, berdasarkan riwayat dari Sufyân dari 'Amru bin Dînar dari Ibnu 'Abbâs bahwa Rasul saw bersabda: "tidak ada susuan kecuali sampai masa dua tahun". ${ }^{11}$

\section{Hikmah Menyusui}

Allah swt memerintahkan kepada para ibu untuk menyusui anak-anaknya, dan memberi batas hingga dua tahun penuh bukan tanpa maksud, diantaranya karena pada masa itu anak-anak masih sangat memerlukan ASI. Sesudah itu baru dia mulai merasakan makanan dan minuman lainnya. Sedang ASI tidak dapat dibandingkan dengan air susu lainnya. Itu adalah makanan anak yang terbaik sebagaimana

\footnotetext{
${ }^{27}$ Muhammad bin Ahmad bin Abu Bakar Al-Qurthubiy, Al-Jâmi' li Ahkâmi Al-Qur'ân, jilid 4, (Beirut: Risalah Publisher, 2006), h. 108

${ }^{28}$ Muhammad 'Ali Al-Shabuniy, Rawâi’ Al-Bayân Tafsîr Âyât min Al-Qur'ân,jilid 1, h. 356

${ }^{29}$ Wahbah Al-Zuhailiy, Tafsîr al Munîr, jilid 1, h. 733

${ }^{30}$ Ibid, h. 735

${ }^{31}$ Muhammad bin Ahmad bin Abu Bakar Al-Qurthubiy, Al-Jâmi' li Ahkâmi Al-Qur'ân, jilid 4, h. 110
} 
dikemukakan oleh para ahli kedokteran. Dengan ASI itulah anak dapat membentuk dirinya dari darah ibu. Darah ini kemudian beralih menjadi susu, dan susu itulah yang menjadi makanan bayi. Pemberian ASI inilah yang akan membatu anak memulai kehidupannya dengan baik. ${ }^{32}$

Disinilah hikmah itu dirasakan, bahwa ASI lah yang sangat cocok bagi anak sesuai dengan tingkatan umur anak. Oleh karena itu, kalau si anak disusukan kepada orang lain, maka kesehatan ibu yang akan menyusukan itu harus dicek terlebih dahulu. Termasuk juga akhlak dan wataknya, Karena ASI sangat berpengaruh, tidak hanya pada perkembangan fisiknya, tapi akhlak dan watak anak juga akan terpengaruh. Hal itu disebabkan air susu ini berasal dari darah ibu yang kemudian dihisap oleh anak, dan itu pulalah yang akan menjadi darah dan daging serta tulang si anak. Itulah sebabnya ASI sangat berpengaruh bagi perkembangan akhlak anak. Bahkan hasil penelitian menunjukkan bahwa ASI lebih berpengaruh pada akhlak anak dibanding dengan jasmaninya. ${ }^{33}$ Lantas bagaimana pengaruh terhadap akal, sensitifitas dan karakter?

Seorang ibu sewaktu menyusui anak, ia tidak sekedar menyusui, tetapi dengan penuh perasaan kelembutan, kasih sayang dan belaian. Dengan demikian, perasaan sayang itulah yang akan tumbuh pada diri seorang anak, juga rasa cinta dan kebaikan. Sebaliknya, orang yang tidak pernah mendapatkan kasih sayang seorang ibu, mereka merasakan dirinya terbelenggu, lalu akan timbul karakter yang keras, jahat dan dendam.

Pakar pendidikan telah mengadakan penelitian terhadap masyarakat yang moralitasnya tinggi, diantara sebabnya adalah pada istri-istri Kaisar pada waktu itu menyusui anak-anaknya sendiri, mereka tidak mau menyerahkan anak-anak mereka kepada perempuan lain untuk menyusukannya. ${ }^{34}$

Dari kesemuanya itu adalah menjadi hal yang sangat mengagumkan, jika syariat menyusui ini dipelajari, dipahami dan direnungkan dengan hati dan pikiran yang jernih, maka yang ditemukan adalah keagungan Allah swt. Betapa Allah tidak menciptakan segala sesuatu itu sia-sia tanpa nilai. ${ }^{35}$ Dan belum pernah ada suatu agama atau kepercayaan apapun dalam masalah pendidikan anak sehebat ajaran Islam. ${ }^{36}$

\section{Fakta Imiah}

Sebagaimana telah disinggung di awal bahwa ASI adalah makanan terbaik bagi anak dalam masa awal kehidupannya, sebab ASI diketahui mengandung zat gizi yang paling sesuai kualitas dan kuantitasnya untuk perkembangan dan pertumbuhan anak. Hal ini didasarkan pada fakta-fakta hasil temuan ilmiah oleh para ahli, pemerhati dan praktisi ilmu kesehatan. Berikut adalah beberapa fakta temuan ilmiah terkait pemberian ASI kepada anak:

\footnotetext{
${ }^{32}$ Ari Sulistyawati, Buku Ajar Asuhan Kebidanan pada Ibu Nifas, h. 17

${ }^{33}$ Muhammad 'Ali Al-Shabuniy, Rawâi' Al-Bayân Tafsîr Âyât min Al-Qur'ân,jilid 1, h. 359

${ }^{34} \mathrm{Ibid}$

${ }^{35}$ QS. Âli 'Imrân [3]: 191

${ }^{36}$ Muhammad 'Ali Al-Shabuniy, Rawâi' Al-Bayân Tafsîr Âyât min Al-Qur'ân,jilid 1, h. 359
} 
Pertama, kandungan ASI. Komposisi ASI bersifat spesifik dan pada setiap ibu, berubah dan berbeda dari waktu ke waktu di sesuaikan dengan kebutuhan bayi saat itu. Berikut adalah beberapa kandungan penting dalam ASI: ${ }^{37}$

1. Kolostrum, yaitu cairan encer dan sering berwarna kuning atau jernih yang kaya zat anti infeksi (10-17 kali lebih banyak dari susu matang) dan protein. Kolostrum keluar pada hari pertama hingga hari ketiga. Kolostrum sangat berguna untuk membersihkan zat sisa dari saluran pencernaan bayi dan mempersiapkan untuk makanan yang akan datang. Kolostrum juga diketahui merupakan anti bodi yang sangat baik bagi tubuh bayi karena dapat membunuh kuman dalam jumlah besar sehingga dapat mengurangi resiko kematian. ${ }^{38}$

2. Vitamin, ASI banyak mengandung vitamin baik yang dapat larut dalam lemak seperti vitamin A,D,E dan $\mathrm{K}$, maupun vitamin yang dapat larut dalam air seperti vitamin $\mathrm{C}$, asam nicotinic, B12, B1, B2 dan B6.

3. Zat besi, meskipun ASI mengandung sedikit zat besi yaitu sekitar 0,5-1,0 $\mathrm{mg} /$ liter, namun bayi yang diberi ASI jarang terkena anemia.

4. Zat anti infeksi, ASI mengandung banyak anti infeksi terhadap berbagai penyakit, seperti penyakit saluran pernafasan atas, diare dan penyakit saluran pencernaan.

5. Laktoferin, terdapat banyak dalam ASI yaitu 1-6 mg/ml, namun zat ini tidak terkandung dalam susu sapi. Zat ini berguna untuk menyerap zat besi dan daripencernaan sehingga terhindar dari suplai zat besi yang dibutuhkan oleh organisme patogenik.

6. Faktor bifidus, zat ini meningkatkan perutmbuhan bakteri baik dalam usus bayi (Lactobasilus Bifidus) yang melawan pertumbuhan bakteri patogen.

7. Lisozim, zat ini memiliki kekuatan beberapa ribu kai lebih tinggi dibanding yang terdapat dalam susu sapi. Zat ini berguna untuk melawan serangan E. Coli dan Salmonela.

8. Taurin, merupakan asam amino terbanyak kedua dalam ASI dan tidak terdapat dalam susu sapi. Zat ini berfungsi untuk menutrisi otak.

Kandungan ASI tersebut tidak akan berkurang hingga dua tahun, karena ASI bersifat menyesuaikan dengan kebutuhan anak. Bahkan penelitian menunjukkan bahwa ASI di tahun kedua memiliki kandungan dan energi yang semakin meningkat. Selain itu, ditahun kedua ASI merupakan sumber lemak dan vitamin A yang tidak tergantikan oleh jenis makanan apapun. ${ }^{39}$

Berbagai manfaat menyusui anak terutama ditinjau dari kelengkapan komposisi ASI inilah yang menjadi pertimbangan sebagian ibu ingin menyusui lebih dari dua tahun. Sayangnya, penelitian baru-baru ini yang dilakukan oleh seorang ilmuwan, Benjamin Chaffee, kepada 715 bayi di Brasil, mengungkapkan bahwa, bayi yang

\footnotetext{
${ }^{37}$ Ari Sulistyawati, Buku Ajar Asuhan Kebidanan pada Ibu Nifas, h. 20-22

${ }^{38}$ KEMENKES RI, Profil Kesehatan Indonesia Tahun 2016, (Jakarta: KEMENKES RI, 2017), h. 138

${ }^{39}$ Ibudanmama.com diakses pada 11 April 2018
} 
menyusui lebih dari dua tahun berpotensi mengalami pembusukan gigi. William Bowen, seorang profesor dari University of Rochester Medical Center, New York mengatakan bahwa hal ini dapat terjadi karena dua hal: (1) Kandungan dalam air susu yang berpotensi mendukung terjadinya pembusukan gigi. (2) Aspek fisik yang terjadi selama menyusui. Hal ini dikarenakan, saat bayi menyusui, giginya takkan tersentuh air liur, yang sebenarnya berfungsi melindungi gigi dari bakteri..$^{40}$

Kedua, Psikologi. Menyusui ternyata juga diketahui dapat memberi pengaruh pada psikologi baik ibu maupun anak yang disusui. ${ }^{41}$

1. Psikologi pada ibu. Setelah melahirkan, ibu mengalami perubahan fisik dan fisiologis yang juga mengakibatkan adanya beberapa perubahan psikisnya. Ia mengalami stimulasi kegembiraan yang luar biasa, menjalani eksplorasi dan asimilasi terhadap bayinya, berada di bawah tekanan untuk dapat menyerap pembelajaran yang diperlukan tentang apa yang harus diketahui dan perawatan untuk bayinya. Begitu juga fenomena yang dikenal dengan post partum blues atau baby blues, yaitu sebuah sekuel umum pasca kelahiran- biasanya terjadi pada $70 \%$ wanita. Fenomena ini biasanya dimulai para beberapa hari setelah kelahiran dan berakhir setelah 10-14 hari. Karakteristik post partum blues melipui menangis, merasa letih pasca melahirkan, gelisah, perubahan alam perasaan, menarik diri, serta reaksi negatif terhadap bayi dan keluarga. Dan dengan menyusui secara langsung terutama sesaat pasca melahirkan (IMD) akan menurunkan tekanan tersebut dan memberikan rasa tenang pada jiwa sang ibu.

2. Psikologi pada anak. Sentuhan awal/ kontak kulit antara ibu dan bayi pada menit-menit pertama dan beberapa jam setelah kelahiran diketahui akan berpengaruh pada tumbuh kembang anak. Inilah yang dikenal dengan bounding attachment, yaitu peningkatan hubungan kasih sayang dengan keterkaitan orang tua dan bayi.

Bounding attachment ini bersifat unik, spesifik dan bertahan lama. Dampak positifnya bagi psikologi anak adalah anak merasa dicintai, diperhatikan, mempercayai dan menumbuhkan sikap sosial sehingga anak merasa aman dan berani mengadakan eksplorasi. ${ }^{42}$ Ikatan ini akan terus-menerus bertambah kuat setiap kali ibu menyusui anaknya, sebab ketika menyusui tidak hanya terjadi kontak kulit tetapi juga kontak mata, dimana ibu dan anak saling pandang. Mendengar dan merespon suara antara orang tua dan anaknya. Selain itu dengan meyusui anak akan mengenali aroma susu ibunya. Kenyataan juga menunjukkan bahwa dengan menyusui, dapat memberi menenangkan anak yang 2018

${ }^{40} \mathrm{https}$ //hellosehat.com/parenting/menyusui/menyusui-lebih-dari-dua-tahun/ di akses pada 11 April

${ }^{41}$ Ari Sulistyawati, Buku Ajar Asuhan Kebidanan pada Ibu Nifas, h. 78

${ }^{42}$ Ai Yeyeh Rukiyah dan Lia Yulianti, Asuhan Neonatus Bayi dan Balita, h. 96 
dalam keadaan rewel. Tegasnya terjadi komunikasi yang baik antara anak dan orang tua yang baik untuk perkembangan psikologi anak.

Terlebih kegiatan itu berlangsung selama jangka waktu yang cukup lama, yaitu dua tahun. Sebagian orang menyangkan bahwa menyusui anak hingga dua tahun atau lebih akan membuat anak menjadi manja dan tidak mandiri. Padahal justru anak pada usia ini dapat menentukan dengan sendirinya kapan mereka akan berhenti menyusui. Sehingga para ibu tidak perlu memaksa untuk terburuburu menyapih anak.

\section{Kesimpulan}

Berdasarkan uraian tafsir surat Al-Baqarah ayat 233 dapat disimpulkan bahwa syariat menyusui adalah perintah Allah swt dan merupakan fitrah serta bentuk kemuliaan bagi para wanita yang memiliki anak. Perintah ini dilengkapi dengan pentunjuk batasan waktu kesempurnaannya yaitu dua tahun. Ini merupakan tahapan penting dari pendidikan seorang anak, yaitu usia nol sampai dua tahun adalah dalam asuhan ibunya. Dimana nilai pendidikan yang ditanamkan adalah kasih sayang, rasa cinta, perhatian serta sapaan yang lembut. Syariat juga menghendaki adanya peran suami dalam memberi dukungan kepada istri dalam menjalankan amanah menyusui dengan kewajiban memberikan nafkah yang halal dan pakaian yang baik.

Kesimpulan mayoritas imam madzhab bahwa hukum menyusui adalah sunnah berdasarkan dalil-dalil yang ditunjukkan ayat-ayat dalam Alquran. Syariat menyusui yang Allah perintahkan bukan tanpa maksud dan tujuan serta hampa dari hikmah, melainkan penuh dengan bukti-bukti tanda kebesaran kuasa-Nya. Adapun manfaat dan alasan-alasannya telah ditemukan melalui pembuktian-pembuktian ilmiah dan tidak dapat dipungkiri lagi. Betapa syariat menyusui ini dituiukan untuk kemaslahatan ibu dan anak, baik fisik maupun dihindari kecuali dengan alasan- 


\section{DAFTAR PUSTAKA}

Al-Bâqiy,Muhammad Fuâd Abd. Mu'jam Al-Mufahras li Alfâzh Al-Qur'ân Al-Karîm. Kairo: Dar al Hadits. $1346 \mathrm{H}$.

Al-Jazîriy,'Abdurrahmân. Kitab Al-Fiqh 'alâ Madzâhibi Al-Arba'ah. jilid. 4,. Beirut: Dar al Kutub al 'Alamiyah. 2003.

Al-Qurthubiy,Muhammad bin Ahmad bin Abu Bakar. Al-Jâmi' li Ahkâmi Al-Qur'ân. jilid 4. Beirut: Risalah Publisher. 2006.

Al-Shabuniy,Muhammad 'Ali. Shafwat Al-Tafâsir. jilid. 1. Beirut: Dar Al Qur'ân Al Karîm. 1981/1401 H.

, Rawâi' Al-Bayân Tafsîr Âyât min Al Qur'ân, terj, Ahmad Dzulfikar. jilid I. Depok: Keira. 2016.

Al-Zuhailiy,Wahbah. Tafsîr Al-Munîr. jilid 1. Damaskus: Dar al Fikr. 2009. cet. X.

Fauziah, Aswin. HubunganAntara Pengetahuan DanSikapSuami Tentang Pemberian Asi Eksklusif. Fakultas Kedokteran Universitas Muhammadiyah Surakarta. 2013.

Ibnu Manzhûr, Lisân al 'Arâb, Tt: Tp.

Ibnu Katsîr,Abu al Fidâ'. Tafsir Al-Qur'ân Al-'Azhîm. terj. M. Abdul Ghafar. jilid 1. Jakarta: Pustaka Imam Syafi'i. 2005.

Kementrian Kesehatan RI. Buku Kesehatan Ibu dan Anak. Jakarta: Kemenkes. 1997. Profil Kesehatan Indonesia Tahun 2016. Jakarta: Kemenkes. 2017.

Muslihatun,Wafi Nur. Asuhan Neonatus Bayi dan Balita. Tt: Fitramaya.Tt.

Prabasiwi, Adila. Sandra Fikawati, dan Ahmad Syafiq. ASI Eksklusif dan Persepsi Ketidakcukupan ASI. Kesmas: Jurnal Kesehatan Masyarakat Nasional Vol.9, No.3, Februari, 2015.

Pusat Data dan Informasi Kementrian Kesehatan RI, Situasi dan Analisis ASI Eksklusif. Jakarta: Kemenkes. 2014.

Rukiyah, Ai Yeyeh dan Lia Yulianti Asuhan Neonatus Bayi dan Balita. Jakarta: CV Trans Info Media. 2010.

Sulistyawati,Ari. Buku Ajar Asuhan Kebidanan pada Ibu Nifas. Yogyakarta: CV. Andi Offset. 2009.

Tan,K.L,Factors Associated with Exclusive Breastfeeding among Infants under Sixmonthsof Agein Peninsular Malaysia. International Breastfeeding Journal, Vol.6, 2011.

Tim FKI Ahla Sufah. Tafsir Maqashidi. Libroyo: Lirboyo Press. 2013.

Tim Penyusun. Kamus Bahasa Indonesia. Jakarta: Pusat Bahasa DEPDIKNAS. 2008.

Yunus, Mahmud. Kamus Arab-Indonesia. Jakarta: Hidakarya Agung. 1990. cet. VIII.

https://health.kompas.com/read/2016/09/04/193900323/ayo.lanjutkan.pemberian.asi.sa mpai.usia.dua.tahun.Diakses pada 11 April 2018.

https:/hellosehat.com/parenting/menyusui/menyusui-lebih-dari-dua-tahun/ di akses pada 11 April 2018. 